\title{
PERSEPSI PELAKSANAAN KURIKULUM 2013 SEKOLAH DASAR
}

\author{
Reza Syehma Bahtiar \\ PGSD Universitas Wijaya Kusuma Surabaya \\ syehma@gmail.com
}

\begin{abstract}
The purpose of this study aims (1) to determine the constraints of the implementation of the 2013 curriculum, (2) to find out the efforts to solve the constraints of the implementation of the 2013 curriculum, and (3) to find out the benefits of implementing the 2013 curriculum. Data collected using interview instruments. The collected data is then analyzed using a descriptive approach developed by Miles and Huberman. The results of the study are as follows. First, there are obstacles in the implementation of the 2013 curriculum, namely that there is no readiness from the teacher in implementing the 2013 curriculum, the training obtained is not fully understood by the teacher, the teacher is still confused in authentic assessment, students are confused because there are no subjects, and the subject matter in the student book is very less. Second, there are efforts to resolve the obstacles in implementing the 2013 curriculum, namely holding workshops and seminars periodically to educators, holding workshops and seminars on authentic assessments to educators, providing understanding of the subjects in the 2013 curriculum, and providing material support books or can be obtained from various sources such as the internet. Third, there are benefits of implementing the 2013 curriculum, namely (1) for students to be more enthusiastic in learning, students' ways of thinking are more developed, encouraging students to learn to solve social problems and respect each other, the competencies that students get are not only from knowledge but there are four aspects gained, the classroom atmosphere becomes comfortable and pleasant (2) for the teacher can explain one theme with a lot of material at once, in time learning becomes shorter in providing understanding to students, the teacher learns to better understand the abilities of students from several aspects at once.
\end{abstract}

Keywords: Perception, Curriculum 2013, Elementary School

\section{ABSTRAK}

Tujuan dari penelitian ini adalah (1) untuk mengetahui kendala pelaksanaan kurikulum 2013, (2) untuk mengetahui upaya penyelesaian kendala pelaksanaan kurikulum 2013, dan (3) untuk mengetahui manfaat pelaksanaan kurikulum 2013. Penelitian ini merupakan penelitian deskriptif eksploratif. Data yang dikumpulkan menggunakan instrument wawancara. Data yang terhimpun kemudian dianalisis dengan pendekatan deskriptif yang dikembangakan oleh Miles dan Huberman. Hasil penelitian adalah sebagai berikut. Pertama, terdapat kendala pelaksanaan kurikulum 2013 yaitu belum ada kesiapan dari guru dalam menerapkan kurikulum 2013, pelatihan yang didapatkan belum sepenuhnya dipahami oleh guru, guru masih bingung dalam hal penilaian autentik, siswa bingung karena tidak ada mata pelajaran, dan materi pelajaran pada buku siswa sangat kurang. Kedua, terdapat upaya penyelesaian kendala pelaksanaan kurikulum 2013 yaitu mengadakan 
workshop dan seminar secara berkala kepada pendidik, mengadakan workshop dan seminar tentang penilaian authentic kepada pendidik, memberikan pemahaman tentang mata pelajaran yang ada pada kurikulum 2013, dan memberikan buku penunjang materi atau dapat diperoleh dari berbagai sumber seperti internet. Ketiga, terdapat manfaat pelaksanaan kurikulum 2013 yaitu (1) bagi siswa lebih bersemangat dalam belajar, cara berpikir siswa lebih berkembang, mendorong siswa untuk belajar memecahkan masalah sosial dan saling menghargai, kompetensi yang didapat siswa tidak hanya dari pengetahuan saja tetapi ada empat aspek yang didapat, suasana kelas menjadi nyaman dan menyenangkan (2) bagi guru dapat menjelaskan satu tema dengan banyak materi sekaligus, dalam pembelajaran waktu menjadi lebih singkat dalam memberikan pemahaman kepada siswa, guru belajar lebih memahami kemampuan siswa dari beberapa aspek sekaligus.

Kata Kunci: Persepsi, Kurikulum 2013, Sekolah Dasar

\section{A. Pendahuluan}

Pengembangan Kurikulum 2013 merupakan langkah lanjutan Pengembangan Kurikulum Berbasis Kompetensi (KBK) yang telah dirintis pada tahun 2004 dan Kurikulum Tingkat Satuan Pendidikan (KTSP) 2006 yang mencakup kompetensi sikap, pengetahuan, dan keterampilan secara terpadu. Kurikulum dapat diartikan sebagai sesuatu berjalan dan berlaku selama beberapa waktu tertentu dan perlu direvisi secara berkala agar tetap relevan dengan perkembangan zaman (Islam, 2017). Pengembangan Kurikulum 2013 mengacu pada standar nasional pendidikan. Tujuannya adalah untuk menjamin pencapaian tujuan pendidikan nasional. Standar nasional pendidikan terdiri atas standar isi, proses, kompetensi lulusan, pendidik dan tenaga kependidikan, sarana dan prasarana, pengelolaan, pembiayaan dan penilaian pendidikan. Standar Isi (SI) dan Standar Kompetensi Lulusan (SKL) merupakan acuan utama bagi satuan pendidikan dalam mengembangkan kurikulum.

Selain itu penyusunan Kurikulum 2013 adanya elemenelemen perubahan yang signifikan. Perubahan ini harus dapat menjadi acuan bagi satuan pendidikan untuk dapat melaksanakan kurikulum 2013 dengan penuh percaya diri. Konsep kurikulum 2013 ini menuntut guru agar menerapkan pembelajaran berbasis tematik-integratif (Wangid, Mustadi, Erviana, \& Arifin, 2014). Pada kegiatan inti dikembangkan pendekatan ilmiah yaitu pendekatan saintifik. Pembelajaran dengan 
pendekatan saintifik adalah proses pembelajaran yang dirancang sedemikian rupa agar peserta didik secara aktif mengonstruk konsep, hukum atau prinsip melalui tahapantahapan mengamati (untuk mengidentifikasi atau menemukan masalah), merumuskan masalah, mengajukan atau merumuskan hipotesis, mengumpulkan data dengan berbagai teknik, menganalisis data, menarik kesimpulan dan mengomunikasikan konsep, hukum atau prinsip yang ditemukan (Diani, 2016). Selain pendekatan saintifik pada kurikulum 2013 juga ada proses penilaian autentik. Pelaksanaan penilaian pada Kurikulum 2013 secara eksplisit meminta agar guruguru di sekolah seimbang dalam melakukan penilaian di tiga ranah domain, yaitu kognitif, afektif dan psikomotor sesuai dengan tujuannya yang hendak diukur (Setiadi, 2016). Penilaian autentik adalah penilaian yang dilakukan secara komprehensif untuk menilai sikap, pengetahuan, keterampilan mulai dari masukan (input), proses, sampai keluaran (output) pembelajaran (Munawati, 2017).

Desentralisasi pengelolaan pendidikan yang diharapkan dapat memenuhi kebutuhan dan kondisi daerah harus segera dilaksanakan. Bentuk nyata desentralisasi pengelolaan pendidikan adalah diberikannya kewenangan kepada satuan pendidikan untuk mengambil keputusan berkenaan dengan pengelolaan pendidikan, seperti dalam pengelolaan kurikulum, baik dalam penyusunan maupun pelaksanaannya di satuan pendidikan. Kurikulum SDN 02 Badegan Kabupaten Ponorogo mengembangkan nilai-nilai budaya dan karakter bangsa sebagai satu kesatuan kegiatan pendidikan yang terjadi di sekolah. Nilai-nilai yang dimaksud di antaranya: religius, jujur, toleransi, disiplin, kerja keras, kreatif, mandiri, demokratis, rasa ingin tahu, semangat kebangsaan, cinta tanah air, menghargai prestasi, komunikatif, cinta damai, gemar membaca, peduli sosial dan lingkungan, serta tanggung jawab. Nilai-nilai yang melingkupi dan terintegrasi dalam seluruh kegiatan pendidikan sebagai sistem budaya sekolah.

Permasalahan yang akan dibahas pada studi lapangan ini adalah (1) apa kendala pelaksanaan kurikulum 2013 ?; (2) bagaimana upaya penyelesaian kendala 
pelaksanaan kurikulum 2013 ? ; dan (3) apa manfaat pelaksanaan kurikulum 2013 ?. Sedangakan tujuan dari studi lapangan ini adalah (1) untuk mengetahui kendala pelaksanaan kurikulum 2013, (2) untuk mengetahui upaya penyelesaian kendala pelaksanaan kurikulum 2013, dan (3) untuk mengetahui manfaat pelaksanaan kurikulum 2013.

\section{B. Metode Penelitian}

Penelitian ini merupakan penelitian deskriptif eksploratif yang mendeskripsikan dan mengungkap implementasi kurikulum 2013. Subjek penelitian adalah guru kelas III SDN 02 Badegan Ponorogo yang berada di Dukuh Nglambong Desa Badegan Kec Badegan Kabupaten Ponorogo.

Data yang dikumpulkan menggunakan instrument wawancara. Ruang lingkup yang akan dieksplorasi pada kegiatan penelitian ini adalah (1) kendala pelaksanaan kurikulum 2013, (2) upaya penyelesaian kendala pelaksanaan kurikulum 2013, dan (3) manfaat pelaksanaan kurikulum 2013.

Data yang terhimpun kemudian dianalisis dengan pendekatan deskriptif yang dikembangakan oleh Miles dan Huberman. Tahap analisis data mencakup data reduction, data display, dan conclusion drawing/verification. Proses analisis dimulai dari kegiatan merekap data yang kemudian dilakukan reduksi data berupa penyederhanaan data dengan cara memilah-milah data yang sesuai kebutuhan penelitian. Data hasil reduksi digolongkan sesuai dengan desain analisis yang selanjutnya dilakukan display. Selanjutnya setelah data display terverifikasi maka diambil kesimpulan penelitiaan.

\section{Hasil Penelitian dan Pembahasan}

Berdasarkan data dari kegiatan wawancara terhadap guru kelas III SDN 02 Badegan Ponorogo, maka diperoleh hasil penelitian yang dibahas pada penjelasan berikut ini:

\section{Kendala Pelaksanaan Kurikulum 2013}

Berdasarkan hasil wawancara di lapangan, terdapat beberapa kendala dalam pelaksanaan kurikulum 2013 yang disampaikan oleh pendidik kelas III SDN 02 Badegan Ponorogo sebagai berikut : 
a. Belum ada kesiapan dari guru dalam menerapkan kurikulum 2013.

Kurikulum yang terkesan mendadak dan belum siap bagi beberapa daerah kecil seperti di Kabupaten Ponorogo menjadi kendala guru dalam kesiapan yang cenderung sangat kurang. Guru dibebani materi dan cara menerapkan kurikulum yang belum jelas dan dimengerti bagi guru. Dengan demikian guru mempersiapkan sendiri dengan otodidak cara penerapan kurikulum 2013.

b. Pelatihan yang didapatkan belum sepenuhnya dipahami oleh guru

Pelatihan memang sudah dilakukan tetapi belum maksimal dalam hal pemahaman dari guru. Hal ini disebabkan oleh waktu yang sangat terbatas dalam pelatihan yang dilaksanakan. Serta kurang adanya tindak lanjut yang seharusnya diperlukan guna pemahaman kurikulum 2013 oleh guru.

c. Guru masih bingung dalam hal penilaian autentik

Dalam hal penilaian memang dirasa sangat menyulitkan bagi guru terutama dalam kurikulum 2013 menggunakan penilaian autentik. Hal ini mendorong guru terletak pada posisi kebingungan yang tinggi karena pada kurikulum sebelumnya penilaian didasarkan aspek pengetahuan tetapi pada kurikulum 2013 menggunakan empat aspek yang harus dipenuhi dalam penilaian yaitu aspek spiritual, sosial, pengetahuan, dan keterampilan.

d. Siswa bingung karena tidak ada mata pelajaran

Kebiasaan siswa yang mengetahui mata pelajaran menjadi kendala dalam pelaksanaan kurikulum 2013. Siswa saat pembelajaran mendapat materi tema yang mencakup beberapa mata pelajaran dan bukan satu mata pelajaran seperti sebelumnya.

e. Materi pelajaran pada buku siswa sangat kurang

Hal ini yang membuat guru dan siswa kebingungan tentang materi. Pada buku siswa yang didapatkan hanya sebagian kecil saja sehingga terkadang siswa malah meremehkan materi yang didapat dari buku siswa karena materi yang sangat kurang.

\section{Upaya Penyelesaian Kendala}

Pelaksanaan Kurikulum 2013

Berdasarkan

kendala

pelaksanaan kurikulum 2013 yang 
Pendas : Jurnal IImiah Pendidikan Dasar, ISSN Cetak : 2477-2143 ISSN Online : 2548-6950 Volume IV Nomor 2, Desember 2019

diungkapkan oleh pendidik kelas III SDN 02 Badegan Ponorogo dapat dilakukan upaya penyelesaian kendala kurikulum 2013 sebagai berikut :

a. Mengadakan workshop dan seminar secara berkala kepada pendidik

Workshop dan seminar secara berkala sangat dibutuhkan oleh guru mengingat kurikulum 2013 merupakan hal yang baru dan perlu dipahami secara mendalam oleh guru. Hal ini perlu dilakukan karena untuk mencapai tujuan pembelajaran yang maksimal, guru perlu memahami terlebih dahulu kemudian menerapkan kurikulum 2013.

b. Mengadakan workshop dan seminar tentang penilaian authentic kepada pendidik

Workshop dan seminar tentang penilaian autentik sangat diperlukan guru, mengingat bukan hanya pemahaman tentang kurikulum 2013 saja tetapi juga diikuti leh pemahaman tentang penilaian autentik.

c. Memberikan

pemahaman tentang mata pelajaran yang ada pada kurikulum 2013

$\mathrm{Hal}$ ini dapat mengurangi bahkan menghilangkan kebingungan siswa

dengan

memberikan pemahaman tentang mata pelajaran yang ada pada kurikulum 2013. Guru hendaknya memberikan penjelasan dan pemahaman kepada siswa agar siswa menghilangkan secara perlahan-lahan tentang kurikulum lama yang menekann=kan pada fokus mata pelajaran.

d. Memberikan buku penunjang materi atau dapat diperoleh dari berbagai sumber seperti internet.

Buku penunjang materi sangat dibutuhkan dalam pengaplikasian kurikulum 2013. Hal ini dilakukan untuk mengatasi materi yang kurang dalam buku siswa.

\section{Manfaat pelaksanaan kurikulum} 2013

Selain memiliki kendala dalam pelaksanaannya, kurikulum 2013 juga memiliki manfaat. Berikut adalah beberapa manfaat pelaksanaan kurikulum 2013.

a. Bagi siswa

1) Lebih bersemangat dalam belajar

Siswa diajak belajar dengan tidak hanya didalam kelas, melainkan bisa dilaksanakan diluar kelas juga. Dengan hal ini pada kurikulum 2013 siswa akan lebih semangat dalam 
belajar karena setidaknya menghilangkan rasa bosan belajar didalam kelas.

2) Cara berpikir siswa lebih berkembang

Siswa akan lebih berkembang dalam proses berpikir karena siswa tidak hanya meningkatkan pada aspek pengetahuan saja melainkan dari empat aspek yaitu aspek spiritual, sosial, pengetahuan, dan keterampilan.

3) Mendorong siswa untuk belajar memecahkan masalah sosial dan saling menghargai.

Di dalam kehidupan mereka nanti pada saat bermasyarakat di usia dewasanya, siswa-siswa kelas rendah sangat perlu untuk menguasai berbagai keterampilan sosial. Mereka harus mampu dan mempuanyai keterampilan bekerjasama di dalam kelompoknya, melakukan kolaborasi dengan berbagai rekan kerja atau siapa saja, belajar berada di dalam kelompok, dan kemampuan memecahkan konflik di antara anggota kelompok yang selanjutnya akan mendodong mereka untuk dapat memecahkan masalah sosial di sekitarnya dengan tetap saling menghargai
4) Kompetensi yang didapat siswa tidak hanya dari pengetahuan saja tetapi ada empat aspek yang didapat yaitu aspek spiritual, aspek sosial, aspek pengetahuan, dan aspek keterampilan.

5) Suasana kelas menjadi nyaman dan menyenangkan

Suasana kelas memungkinkan semua orang yang ada di dalamnya (utamanya siswa dan guru) akan mempunyai perasaan bersedia menanggung resiko bersama-sama. Contohnya saja, semua orang yang ada di dalam kelas akan berusaha menanggapi pertanyaan-pertanyaan yang bahkan berupa pertanyaan yang tidak semestinya atau tidak benar tanpa harus menyinggung perasaan sang penanya. Prosedurprosedur kerja keseharian, memastikan bahwa semua jadwal dapat diprediksi, dan terdapat jaminan bahwa siswa akan merasa aman saat berada di kelas maupun di luar kelas. Keterampilan hidup yang dipelajari dapat dikenali, didiskusikan dan dipraktikkan oleh siswa dengan interaksi yang tepat dan dengan perasaan senang di dalam komunitasnya di ruang kelas.

b. Bagi guru 
1)

$$
\text { Guru }
$$

dapat

menjelaskan satu tema dengan banyak materi sekaligus

Dengan kurikulum 2013 guru sangat diuntungkan dengan penyampaian beberapa materi sekaligus dalam satu kali tatap muka. Hal ini membuat guru lebih efisien dalam penyampaian materi pembelajaran pada siswa.

2) Dalam pembelajaran waktu menjadi lebih singkat dalam memberikan pemahaman kepada siswa

Dalam sekali tatap muka guru melakukan penyampaian dan pemahamanbeberapa materi sekaligus. Hal ini tentu mempersingkat waktu daripada menggunakan kurikulum sebelumnya.

3) Guru belajar lebih memahami kemampuan siswa dari beberapa aspek sekaligus seperti aspek spiritual, aspek sosial, aspek pengetahuan, dan aspek keterampilan.

Guru akan diuntungkan dengan pelaksanaan kurikulum 2013 karena guru akan lebih memahami kemampuan siswa dari beberapa aspek sekaligus seperti aspek spiritual, aspek sosial, aspek pengetahuan,

dan

aspek keterampilan. Dengan demikian guru akan lebih paham karakter dan model belajar siswa secara individu.

$$
\text { Inti dari Kurikulum 2013, adalah }
$$

ada pada upaya penyederhanaan, dan tematik-integratif. Kurikulum 2013 disiapkan untuk mencetak generasi yang siap di dalam menghadapi masa depan. Karena itu kurikulum disusun untuk mengantisipasi perkembangan masa depan.

Titik beratnya, bertujuan untuk mendorong peserta didik, mampu lebih baik dalam melakukan observasi, bertanya, bernalar, dan mengkomunikasikan

(mempresentasikan), apa yang mereka peroleh atau mereka ketahui setelah menerima pelajaran. Melalui pendekatan itu diharapkan siswa kita memiliki kompetensi sikap, ketrampilan, dan pengetahuan jauh lebih baik. Mereka akan lebih kreatif, inovatif, dan lebih produktif, sehingga nantinya mereka bisa sukses dalam menghadapi berbagai persoalan dan tantangan di zamannya, memasuki masa depan yang lebih baik.

Pelaksanaan penyusunan kurikulum 2013 adalah bagian dari melanjutkan pengembangan 
Kurikulum Berbasis Kompetensi (KBK) yang telah dirintis pada tahun 2004 dengan mencakup kompetensi sikap, pengetahuan, dan keterampilan secara terpadu, sebagaimana amanat UU 20 tahun 2003 tentang Sistem Pendidikan Nasional pada penjelasan pasal 35, di mana kompetensi lulusan merupakan kualifikasi kemampuan lulusan yang mencakup sikap, pengetahuan, dan keterampilan sesuai dengan standar nasional yang telah disepakati. Paparan ini diharapkan dapat menjaring pendapat dan masukan dari masyarakat. Penyusunan kurikulum 2013 yang menitikberatkan pada penyederhanaan, tematik-integratif mengacu pada kurikulum 2006 di mana ada beberapa permasalahan di antaranya; (i) konten kurikulum yang masih terlalu padat, ini ditunjukkan dengan banyaknya mata pelajaran dan banyak materi yang keluasan dan tingkat kesukarannya melampaui tingkat perkembangan usia anak; (ii) belum sepenuhnya berbasis kompetensi sesuai dengan tuntutan fungsi dan tujuan pendidikan nasional; (iii) kompetensi belum menggambarkan secara holistik domain sikap, keterampilan, dan pengetahuan; beberapa kompetensi yang dibutuhkan sesuai dengan perkembangan kebutuhan (misalnya pendidikan karakter, metodologi pembelajaran aktif, keseimbangan soft skills dan hard skills, kewirausahaan) belum terakomodasi di dalam kurikulum; (iv) belum peka dan tanggap terhadap perubahan sosial yang terjadi pada tingkat lokal, nasional, maupun global; (v) standar proses pembelajaran belum menggambarkan urutan pembelajaran yang rinci sehingga membuka peluang penafsiran yang beraneka ragam dan berujung pada pembelajaran yang berpusat pada guru; (vi) standar penilaian belum mengarahkan pada penilaian berbasis kompetensi (proses dan hasil) dan belum secara tegas menuntut adanya remediasi secara berkala; dan (vii) memerlukan dokumen kurikulum yang lebih rinci agar tidak menimbulkan multi tafsir.

\section{E. Kesimpulan}

Berdasarkan hasil penelitian dan pembahasan diatas dapat diambil simpulan sebagai berikut. Pertama, terdapat kendala pelaksanaan kurikulum 2013 yaitu belum ada kesiapan dari guru dalam 
menerapkan kurikulum 2013, pelatihan yang didapatkan belum sepenuhnya dipahami oleh guru, guru masih bingung dalam hal penilaian autentik, siswa bingung karena tidak ada mata pelajaran, dan materi pelajaran pada buku siswa sangat kurang. Kedua, terdapat upaya penyelesaian kendala pelaksanaan kurikulum 2013 yaitu mengadakan workshop dan seminar secara berkala kepada pendidik, mengadakan workshop dan seminar tentang penilaian authentic kepada pendidik, memberikan pemahaman tentang mata pelajaran yang ada pada kurikulum 2013, dan memberikan buku penunjang materi atau dapat diperoleh dari berbagai sumber seperti internet. Ketiga, terdapat manfaat pelaksanaan kurikulum 2013 yaitu (1) bagi siswa lebih bersemangat dalam belajar, cara berpikir siswa lebih berkembang, mendorong siswa untuk belajar memecahkan masalah sosial dan saling menghargai, kompetensi yang didapat siswa tidak hanya dari pengetahuan saja tetapi ada empat aspek yang didapat yaitu aspek spiritual, aspek sosial, aspek pengetahuan, dan aspek keterampilan, suasana kelas menjadi nyaman dan menyenangkan (2) bagi guru dapat menjelaskan satu tema dengan banyak materi sekaligus, dalam pembelajaran waktu menjadi lebih singkat dalam memberikan pemahaman kepada siswa, guru belajar lebih memahami kemampuan siswa dari beberapa aspek sekaligus seperti aspek spiritual, aspek sosial, aspek pengetahuan, dan aspek keterampilan.

\section{DAFTAR PUSTAKA}

Diani, R. (2016). Pengaruh Pendekatan Saintifik Berbantukan LKS terhadap Hasil Belajar Fisika Peserta Didik Kelas XI SMA Perintis 1 Bandar Lampung. Jurnal IImiah Pendidikan Fisika Al-Biruni, 5(1), 83-93.

https://doi.org/10.24042/jpifalbiru ni.v5i1.108

Islam, S. (2017). Karakteristik Pendidikan Karakter; MenjawabTantangan

Multidimensional Melalui Implementasi Kurikulum 2013. Edureligia, 01(01), 89-101. Retrieved from https://ejournal.unuja.ac.id/index. php/edureligia/article/view/50/46

$\begin{array}{lr}\text { Munawati, } & \text { S. } \\ \text { PELAKSANAAN } & \text { PENILAIAN). } \\ \text { AUTENTIK DI } & \text { SEKOLAH } \\ \text { DASAR } & \text { NEGERI } \\ \text { PUJOKUSUMAN } & \text { I } \\ \text { YOGYAKARTA. } & \text { Jurnal } \\ \text { Pendidikan Guru Sekolah Dasar, } \\ \text { 6(2), 174-183. Retrieved from } \\ \text { http://journal.student.uny.ac.id/oj }\end{array}$


s/ojs/index.php/pgsd/article/view/ $6619 / 6385$

Setiadi, H. (2016). Pelaksanaan Penilaian Pada Kurikulum 2013. Jurnal Penelitian Dan Evaluasi Pendidikan, 20(2), 166-178. https://doi.org/10.21831/pep.v20i 2.7173

Wangid, M. N., Mustadi, A., Erviana, V. Y., \& Arifin, S. (2014). Kesiapan Guru SD dalam Pelaksanaan Pembelajaran Tematik-Integratif pada Kurikulum 2013 di DIY. Jurnal Prima Edukasia, 2(2), 175-182. Retrieved from https://ejournal.unuja.ac.id/index. php/edureligia/article/view/50/46 